\title{
Xenotransplantation: Biotechnological Aspects and Current Attitudes
}

\author{
By Torben Greve
}

Department of Clinical Studies, Reproduction, Royal Veterinary and Agricultural University, Dyrlaegevej 68, DK-1870 Frederiksberg C, Denmark. Voice: +4535282965; fax: +4535282972; e-mail: tg@kvl.dk

\begin{abstract}
Xenotransplantation of organs from the large domestic species will only be successful if the donor animals have been genetically modified, in particular regarding the $\alpha$-Gal epitope, certain human complements (CD55 and CD59) and/or H-transferase. This requires, among other things, major embryo-technological efforts, and the rate of success is still far from an acceptable level in the domestic species. It is currently poor, but the progress is very good. In this brief review certain embryo-technological problems will be addressed with the focus on the pig as potential organ donor. In addition, certain views of the Danish ad hoc Committee on Gene Technology on xenotransplantation will be presented in this context as they are supposed to mirror the concern and the views of the issues important for the public and each individual.
\end{abstract}

Pigs; Nuclear transfer; Transgenesis; Cloning; Bioethics.

\section{Introduction}

Only very few species will be suitable as organ source for humans based solely on size and function. The domestic pig seems to possess many of the required characteristics with regard to organ size and efficiency (7). However, one major problem by using pig organs is the existence of terminal $\alpha$-1,3-galactosyltransferase (abbreviation: the $\alpha$-Gal epitope) on its cell surfaces. Primates including humans do not possess this epitope, they do have natural antibodies against the $\alpha$-Gal epitope, and following transfer of an organ from for example a pig this will lead to the so-called hyperacute rejection (HAR; 5). In order to use pigs as donors it is therefore mandatory to use donors where the Gal-epitope has been "knocked-out", or where genes coding for human compliments have been added to the genome $(2,3)$ or both. Production of transgenic pigs is therefore probably the most important part of producing organs for xenotransplantation, and in the following some embryo-technological aspects and Danish attitudes towards this new and emerging field of research and clinical application will be addressed. Several excellent reviews are available on this issue (15).

\section{Embryo-technological aspects}

The first transgenic pigs were produced in 1985 by injecting several hundred copies of the human growth hormone gene into one of the pronuclei of newly fertilized pig eggs (8), and this technique is still viable and being used in many laboratories $(13,19,20,21)$. The technique was also used to produce pigs transgenic with respect to the human complement system, CD55 and CD59 $(2,16), \mathrm{H}$ transferase (3) and human decay accelerating factor (14). The average success rate following pronuclear injection is still below $1 \%$, and production of mosaic 
embryos is a pronounced problem $(12,18)$ which does not occur after transfection of somatic cells used for subsequent somatic cell nuclear transfer (SCNT; 17). The pronuclear injection technique will, however, -never allow homologous recombination to remove the $\alpha$ Gal epitope gene i.e., to "knock-out" one or two alleles of this single gene (5). An ample availability of stem cells, genetic modification of these, and SCNT followed by embryo transplantation of one-cell zygotes and delivery of normal live born offspring, are the only ways to obtaining knock-out pigs from which organs may be transplanted without eliciting the HAR. Much effort has consequently been devoted to this attractive alternative. Recently Lai et al. (10) reported that they had produced a-1,3galactosyltransferase knock-out pigs by SCNT. In the same year PPL Therapeutics announced that they had produced piglets, which had displayed a knock-out of one allele coding for the $\alpha$-Gal epitope. The reports quoted above had only one allele knocked-out, but then in 2002, it was reported that transgenic pigs with both alleles silenced had been born at the PPL Therapeutics premises (cited in: Vet Science Tomorrow, August 27, 2002). This step has brought xenotransplantation even closer to reality, and one may now envisage that it is possible to produce herds of pigs from where organs can be used for humans.

There are, however, a number of obstacles, one being the very low efficiency of the embryotechnology. The SCNT technique combined with transgenesis yields egg cleavage rates following fusion and activation of $60-70 \%(9,11)$, blastocyst rates of about $10 \%(9,11)$, mean number of nuclei per blastocyst of about 25-30 $(9,11)$, but very poor production rates of cloned transgenic animals: only 14 transgenic piglets of 338 embryos transferred to 3 recipients (10) and one transgenic piglet of 150 transferred embryos (11). This is less than $0.03 \%$ pig born per transplanted cloned transgenic embryo. In addition, the offspring may have a higher incidence of malformations, such as deformations of the extremities (10). Recent Danish data using a zona free manipulation technique to perform somatic nuclear transfer showed that $85 \%$ were successfully fused and survived activation, and that the total blastocyst rate was approximately 5\% with the blastocysts containing an average of about 35 cells. It should be emphasized that these were non-transgenic (1).

The embryo-technological aspects of manufacturing SCNT and cloned embryos is far from being perfect, but the progress in SCNT in combination with the advancement at the molecular biology front, and in particular in homologous recombination, will undoubtedly bring us very rapidly forward with the final goal, i.e. to produce offspring possessing the genotypes which render them suitable as organdonors.

\section{Danish attitudes}

The Danish ad hoc Committee on Gene Technology was set up as a consequence of a debate in the Danish Parliament (Folketinget) in January 2001, and one of the issues to be discussed was xenotransplantation. The report by the committee was published on October 24th, 2002. In the following, some points from this report will be presented (4).

Xenotransplantation would in principle provide an unlimited number of organs such as kidneys, hearts and livers for transplantation to humans. Cells from genetically modified animals may be used to repair degenerated or dead cells in different parts of the human body. There are, however, a number of problems inherent to implementation of this technology. As mentioned earlier there is the problem of the hyperacute reaction (HAR), which might be overcome by use of organs from knock-out pigs. But other rejections will occur, and it means that the individual 
should be on immunosuppressive medicine for the rest of her or his life. Of even greater societal concern is the risk for spreading diseases between man and animals and thus creating new epidemics and zoonosis of already known or entirely new diseases. The porcine endogene retrovirus (PERV) is of major concern as it replicates in the genome. Recent data from mice have clearly shown that it is a real problem particularly in immunosuppressed animals. Prion mediated diseases are also in focus. Due to these precautions it is very likely that the person receiving the organ and the family would stay in solitary confinement for a certain period of time. They may also have to submit to travel restrictions to certain international destinations, from where diseases important, not only for humans but also for animals, may be imported into Denmark and subsequently be disseminated in the domestic human and/or animal populations.

Thus rejection and diseases are major concerns, but in addition the problems of functionality of pig organs in humans have been addressed. The literature is limited in this field, but there are obvious anatomical and functional differences between human and pig organs. Just to mention a few: cardiac output, stroke volume, heart valves, blood viscosity, posture (upright versus horizontal) affecting inhalation and exhalation, liver perfusion, molecular differences regarding hormones, receptors and enzymes of the kidney and liver $(6,7)$. It is virtually unknown how, for example, a pig heart will function in a human body providing it is not rejected. And how will the blood pressure be maintained following transplantation of a pig kidney?

The ethical issues have been divided in two categories; on one hand the human ethical aspects, and on the other the animal ethical problems.

In the human ethical field it is on one hand the ability to replace human organ by xeno- rather than heterotransplantation and, thus, the ability to cure terminally ill people. This is of paramount importance. On the other hand, is the individual integrity being equally important. Would xenotransplantation mean that the borderline between man and animals is crossed? Another important issue is the respect for the autonomy of the patient. It is likely that all patients receiving an animal organ, will be under public surveillance and control, and is that desirable? What about extended quarantine? And must the family be submitted to the same regulations?

It is obviously also very important that harm is not inflicted upon others, and preventing that will really require strict regulations from the involved authorities.

Animal ethical considerations must also be taken into account. It is known that SCNT combined with transgenesis may elicit unwanted side effects (malformations, poor survival) which in turn cause suffering and pain. All necessary precautions must be taken to avoid this, and one should weight these against the benefits. Rearing of the animals may also be fairly restricted leading to stressful conditions. It has been suspected that pigs transgenic for the aGal epitope, may have certain subtle eye diseases.

It should, finally, be mentioned that implementation of xenotransplantation probably will be expensive and thus, place further stress on a health system already strained from constant pressure, to implement new and advanced technologies.

\section{Concluding remarks}

Whether xenotransplantation will ever be a realistic alternative to heterotransplantation, is still an open question. It will require not only advanced basic research, but also a great deal of clinical investigations, and this will undoubtedly cause some degree of suffering in the initial phase. The recent availability of knock-out 
pigs and the attenuation this represents of one of the most unwanted side effects, namely HAR, has given some hope to many patients urgently in need for a new organ.

\section{References}

1. Booth P, Tan SJ, Holm P, Callesen H: Application of the zona-free manipulation technique to porcine somatic nuclear transfer. Cloning Stem Cells 2001, 3, 191-197.

2. Cowan P. Renal xenografts from triplet-transgenic pigs showing prolonged survival in non immunosuppressed Baboons. In: Transgenic Animals in Research, Tahoe City, August 15-19, 1999, 31-32.

3. Fodor $W$ : The development of transgenic livestock for biomedical purposes. In: Transgenic Animals in Research, Tahoe City, August 15-19, 1999, 30.

4. Fremtidens bioteknologier - muligheder og risi$c i$ : Ministeriet for Videnskab, Teknologi og Udvikling, København. 2002, 188 pp.

5. Galili, Sohet, SB, Kobrin E: Man, apes and Old World monkeys differ from other mammals in the expression of alpha-galactosyl epitopes on nucleated cells. J. Biol. Chem. 1988, 263, 17755-17762.

6. Hammer $C$ : Fundamental problems of xenotransplantation. Path Biol. 1994, 42, 203-207.

7. Hammer $C$, Linke R, Wagner F, Diefenbeck M: Organs from animals to man. Int. Arch. Allergy Immunology 1998, 116, 5-21.

8. Hammer RE, Pursel G, Rexroad Jr CE, Wall RJ, Bolt DJ, Ebert KM, Palmiter RD, Brinster RL: Production of transgenic rabbits, sheep and pigs by microinjection. Nature (Lond.) 1985, 315, 680-683.

9. Koo D-B, Kang Y-K, Choi Y-H, Park JS, Kim H$N$, Kim T, Lee K-K, Han Y-M: Development potential and transgene expression of porcine nuclear transfer embryos using somatic cells. Mol. Reprod. Develop. 2001, 58, 15-21.

10. Lai L, Kolber-Simonds D, Park KW, Cheong $H$ T, Greenstein JL, Im G-S, Samuel M, Bonk A, Rieke, A, Day BN, Murphy CN, Carter DB, Hawley RJ, Prather RS: Production of a-1.3-galactosyltransferase knockout pigs by nuclear transfer cloning. Science 2002, 295, 1089-1092.

11. Lai L, Park K-W, Cheong H-T, Kühholzer B, Samuel M, Bonk AA, Im G-S, Rieke A, Day BN, Murphy CN, Carter DB, Prather RS: Transgenic pig expressing the enhanced green fluorescent protein produced by nuclear transfer using colchicine-treated fibroblasts as donor cells. Mol. Reprod. Develop. 2002, 62, 300-306.

12. Macháty Z, Bondioli K, Jagdeece JR, Fodor WL. The use of nuclear transfer to produce transgenic pigs. Cloning Stem Cells, 2002, 4, 21-27.

13. Martin MJ, Houtz J, Adams C, Thomas D, Freeman B, Keims J, Cottrill F: Effect of pronuclear DNA microinjection on the development of porcine OVA in utero. Theriogenology 1996, 46, 695-701

14. Murakami H, Nagashima H, Takahagi Y, Miyagawa S, Fujimura T, Toyomura K, Nakai R, Yamada $M$, Kurihara T, Shigehisa T, Okabe $M$, Seya T, Shirakura R, Kinoshita T: Transgenic pigs expressing human decay-accelerating factor regulated by porcine MCP gene promoter. Mol. Reprod. Develop. 2002, 62, 302-311.

15. Niemann H, Kues WA: Transgenic livestock: premises and promises. Anim. Reprod. Sci. 2000, 60-61, 277-293.

16. Niemann $H$, Kues $W$, Hermann D, Lemme $E$, Hauser HJ, Verhoyen E, Schwinzer R, Paul D: Generation and characterization of pigs transgenic for human CD59 constructs. Immunobiology 1999, 200, 492.

17. Park K-W, Lai L, Cheong H-T, Cabot R, Sun $Q$ $Y$, Wu G, Rucker EB, Durtschi D, Bonk AA, Samuel M, Rieke A, Day BN, Murphy CN, Carter $D B$, Prather RS: Mosaic gene expression in nuclear transfer-derived embryos and the production of cloned transgenic pigs from ear-derived fibroblasts. Biol. Reprod. 2002, 66, 1001-1005.

18. Peippo J: Sex-related development in embryos. Thesis, University of Turku, Turku, 2001.

19. Pursel VG, Bolt DJ, Miller KF, Pinkert CA, Hammer RE, Palmiter RD, Brinster RL: Expression and performance in transgenic pigs. J. Reprod. Fertil. Suppl. 1990, 40, 235-245.

20. Pursel VG, Rexroad Jr CE: Recent progress in the transgenic modification of swine and sheep. Mol. Reprod. Develop. 1993, 36, 251-254.

21. Wall RJ: Transgenic livestock: progress and prospects for the future. Theriogenology 1996, $45,57-68$. 


\section{Sammendrag}

Xenotransplantation: bioteknologiske aspekter og danske holdninger.

Transplantation af organer fra vore husdyr forudsætter, at de er genetisk modificeret (transgene) specielt med hensyn til den såkaldte $\alpha$-Gal epitop, visse humane komplementfaktorer (CD55 og CD59) og/ eller $\mathrm{H}$-transferase. Fremstilling af transgene grise er en kompliceret proces med fortsat lav succes. Forkerne injektioner giver under $1 \%$ afkom og kombinationen af kloning og genetisk modifikation er endnu mindre effektiv $(0,03 \%)$. Sidstnævnte teknik er imid- lertid en forudsætning for, at man kan fremstille knock-out grise, hvor generne, som koder for $\alpha$-Gal epitopen, er gjort tavse. Disse aspekter omtales i artiklen. Det danske Genteknologiudvalg, som blev nedsat af Ministeriet for Videnskab, Teknologi og Udvikling afleverede sin rapport den 24. oktober 2002 og en række af dette udvalgs konklusioner omtales i den sidste del af artiklen. Herunder afstødnings- og smitte problematikken, human etiske og dyreetiske overvejelser samt hvilke myndigheder, som har ansvar for at de forskellige anbefalinger føres videre i systemet. Rapporten kan erhverves på www.videnskabsministeriet.dk 